\title{
Regulation of Calmodulin- and Dopamine-Stimulated Adenylate Cyclase Activities by Light in Bovine Retina
}

\author{
Margaret E. Gnegy, Nancy Muirhead, and Jeffrey K. Harrison \\ Department of Pharmacology, The University of Michigan, Ann Arbor, Michigan, U.S.A.
}

\begin{abstract}
Neural retina from most species contains 3,4dihydroxyphenylethylamine (dopamine) receptors coupled to stimulation of adenylate cyclase activity. It has been demonstrated that release of dopamine from its neurons and subsequent occupation of dopamine receptors is increased by light. In this study, we have shown that adenylate cyclase activity in bovine retina is highly responsive to the endogenous $\mathrm{Ca}^{2+}$-binding protein, calmodulin, and that calmodulin can increase dopamine-sensitive adenylate cyclase activity in bovine retina. We further demonstrate that both dopamine- and calmodulinstimulated adenylate cyclase activities can be regulated by alterations in light. Bovine retinas were dissected from the eye under a low-intensity red safety light, defined as dark conditions, and incubated for $20 \mathrm{~min}$ in an oxygenated Krebs Henseleit buffer under either dark or light conditions. The retinas were then homogenized and adenylate cyclase activity measured in a particulate fraction washed to deplete it of endogenous $\mathrm{Ca}^{2+}$ and calmodulin. Activation of adenylate cyclase activity by calmodulin, dopamine, and the nonhydrolyzable GTP analog, guanosine- $5^{\prime}-(\beta, \gamma$-imido)triphosphate (GppNHp), was significantly $(60 \%)$ greater in particulate fractions from retinas that had been incubated under dark conditions as compared to those incubated under light conditions. Basal,
\end{abstract}

$\mathrm{Mn}^{2+}-$, and GTP-stimulated adenylate cyclase activities were not altered by changes in lighting conditions. Calmodulin could increase the maximum stimulation of adenylate cyclase by dopamine in retinas incubated under either dark or light conditions, but the degree of its effect was greater in retinas incubated under light conditions. Activation of adenylate cyclase by calmodulin, dopamine, and GppNHp in particulate fractions from retinas incubated under light conditions was indistinguishable from the activation obtained when retinas were incubated in the dark in the presence of exogenous dopamine. These results suggest that an increased release of dopamine occurs in light. The decreased response of adenylate cyclase to exogenous dopamine can then be explained by a subsequent down-regulation of dopamine receptor activity. The down-regulation of dopamine receptor activity can also regulate activation of adenylate cyclase by GppNHp and calmodulin. The results suggest that dopamine, calmodulin, and GppNHp are modulators of a common component of adenylate cyclase activity, and this component is regulated by light. Key Words: Calcium-DopamineCyclic AMP-Guanyl nucleotides-Receptor regulation. M. E. Gnegy et al. Regulation of calmodulin- and dopamine-stimulated adenylate cyclase activities by light in bovine retina. $J$. Neurochem. 42, 1632-1640 (1984).
3,4-Dihydroxyphenylethylamine (dopamine or DA) is fairly well established as a neurotransmitter in the retina. In most species, DA is localized either in a certain class of amacrine cells or in interplexiform cells, as in the teleost fish (Dowling and Ehinger, 1978). These neurons have the capacity to synthesize, degrade, and release DA (Kramer, 1971; Thomas et al., 1978). Although the exact role of DA is not known in the retina, its physiological action is seemingly inhibitory (for review, see Lolley, 1980).

Postsynaptic DA receptors in neural retina are predominantly of the D-1 type, that is, coupled to a stimulation of adenylate cyclase activity (Brown and Makman, 1972; Watling et al., 1979). Recently, however, receptor binding studies have shown the presence of D-2 type receptors in mammalian retina (Makman et al., 1980; Watling and Iversen, 1981). DA-stimulated adenylate cyclase activity has been measured in retinal homogenate and particulate fractions, as well as in intact retina in several species (Brown and Makman, 1972; Watling et al., 1979; Redburn et al., 1980; Watling and Dowling, 1981; Ferrendelli et al., 1982). The DA system in the retina is responsive to changes in illumination; light has been shown to elicit a release of DA from its neurons (Kramer, 1971). DA biosynthesis and tyrosine hydroxylase activity are concomitantly in-
Received September 12, 1983; accepted November 28, 1983.

Address correspondence and reprint requests to Margaret E. Gnegy, Department of Pharmacology, The University of Michigan, Ann Arbor, MI 48109, U.S.A.
Abbreviations used: CaM, Calmodulin; DA, 3,4-Dihydroxyphenylethylamine (dopamine); GppNHp, Guanosine-5'-( $\beta, \gamma-$ imido)triphosphate. 
creased in retina from rats exposed to light (Iuvone et al., 1978). Watling et al. (1980) found that flashing lights, which activate interplexiform cells in carp, increased cyclic AMP levels in the retina and the effect was blocked by haloperidol. DA receptor activity may respond to changes in DA levels elicited by alterations in light. Spano et al. (1977) found that DA had a greater ability to increase adenylate cyclase activity in retinas from rats that had been kept in the dark for $65 \mathrm{~h}$. The increase in response to DA may be due to a supersensitivity of the postsynaptic DA receptors that developed as a result of the long-term decrease in release of DA.

Our previous studies in rat striatum have suggested that the endogenous $\mathrm{Ca}^{2+}$-binding protein, calmodulin $(\mathrm{CaM})$, may play a role in modulating the sensitivity of adenylate cyclase to DA (Gnegy and Treisman, 1981; Gnegy, 1982). We have found that bovine retina contains $\mathrm{CaM}$ and a CaM-sensitive adenylate cyclase activity that has many characteristics similar to that found in rat brain (Muirhead et al., 1983). Adenylate cyclase activity in bovine retina can be activated over sevenfold by $\mathrm{CaM}$ in a $\mathrm{Ca}^{2+}$-dependent manner. Further, addition of $\mathrm{Ca}^{2+}$ and $\mathrm{CaM}$ doubled the maximal activation of the enzyme by DA. This suggested that CaM could play a role in modulating DA-stimulated adenylate cyclase activity in the retina and that the CaM-stimulated and DA-stimulated adenylate cyclase activities might be related, if not identical. To further explore the relationship between DA-stimulated and CaM-stimulated adenylate cyclase activities we investigated whether they could be similarly regulated by alterations in lighting conditions. We examined the ability of adenylate cyclase to be activated by CaM, DA, and guanyl nucleotides in a particulate fraction depleted of $\mathrm{Ca}^{2+}$ and CaM from bovine retinas that had been preincubated under either white light ("light conditions") or a low-intensity red safety light ("dark conditions"). The data demonstrate that adenylate cyclase is activated by $\mathrm{CaM}, \mathrm{DA}$, and the nonhydrolyzable GTP analog, guanosine-5'-( $\beta, \gamma$-imido)triphosphate (GppNHp) to a greater extent in retinas that have been incubated under dark conditions as compared to those incubated under light conditions. Thus, stimulation of adenylate cyclase activity by $\mathrm{CaM}$ appears to be under the same neural regulation as that of DA.

\section{MATERIALS AND METHODS}

\section{Preparation of retinal particulate fractions}

Bovine eyes were obtained fresh from a local slaughterhouse and brought in ice protected from light to the laboratory. Eyes were hemisected at a level posterior to the ora serrata and retinas dissected as described by Watling and Iversen (1981), taking care to tease the retina from the pigment epithelium. Approximately $350-450 \mathrm{mg}$ wet weight tissue was obtained from one eye. Retinas were dissected under a red-filtered (Kodak OC filter) safety light having maximum wavelengths of 600 and 750 $\mathrm{nm}$. The intensity of the light at the level of incidence to the sample was $0.63 \mathrm{lux}$. This will be defined as "dark conditions." For treatments with white light ("light conditions"), a General Electric cool white F400W light was used. The intensity at the level of incidence to the sample was $630 \mathrm{lux}$. The retinas were incubated then under either dark or light conditions at $37^{\circ} \mathrm{C}$ for $20 \mathrm{~min}$ in oxygenated Krebs-Henseleit buffer containing $122 \mathrm{mM} \mathrm{NaCl}, 25 \mathrm{mM}$

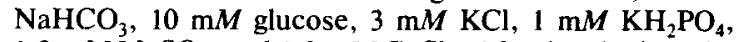
$1.2 \mathrm{mM} \mathrm{MgSO}{ }_{4}$, and $1.3 \mathrm{mM} \mathrm{CaCl}{ }_{2}$. After incubation, the retinas were washed three times in $5 \mathrm{ml}$ of a buffer containing $10 \mathrm{mM}$ Tris maleate, $\mathrm{pH} 7.5$, containing $1.0 \mathrm{mM}$ $\mathrm{MgSO}_{4}$ and $1.2 \mathrm{mM}$ EGTA (Buffer A). The retinas were then homogenized in $2 \mathrm{ml}$ of Buffer $\mathrm{A}$ and centrifuged at $27,000 \times g$ for $20 \mathrm{~min}$. The pellets were washed twice and resuspended finally in $2 \mathrm{ml}$ of Buffer A. Protein was determined by the method of Lowry et al. (1951).

\section{Adenylate cyclase assay}

Adenylate cyclase activity was measured in an assay ( $200 \mu \mathrm{l}$ volume) containing: $80 \mathrm{~m} M$ Tris maleate buffer (pH 7.5), $5 \mathrm{mM} \mathrm{MgSO}$, $2 \mathrm{~m} M$ cyclic AMP, $4 \mathrm{~m} M$ phosphenolpyruvate, $20 \mu \mathrm{g}$ pyruvate kinase, $0.12 \mathrm{mM}$ isobutylmethylxanthine, $100-150 \mu \mathrm{g}$ of particulate membrane protein, $0.15 \mathrm{~m} M$ EGTA, and $1 \mathrm{~m} M\left[\alpha{ }^{-32} \mathrm{P}\right] A T P(1 \mu \mathrm{Ci}$ per assay), with or without additions such as GppNHp, $\mathrm{GTP}, \mathrm{CaCl}_{2}$, and $\mathrm{CaM}$. Assays were incubated for $10 \mathrm{~min}$ and the reaction was stopped by heating for $1 \mathrm{~min}$ at $95^{\circ} \mathrm{C}$. A solution containing $20 \mathrm{mM}$ ATP and $0.7 \mathrm{mM}\left[{ }^{3} \mathrm{H}\right]$ cyclic AMP (200 $\mu$ l volume) was then added to the tubes. The particulate material was centrifuged, and the [ $\left.{ }^{32} \mathrm{P}\right]-$ labelled cyclic AMP in the supernatant fraction was determined by the method of Krishna et al. (1968). Recovery of the cyclic AMP was measured using the $\left[{ }^{3} \mathrm{H}\right]$ cyclic AMP and was usually $80-90 \%$. Free or effective concentrations of $\mathrm{Ca}^{2+}$ were calculated using a dissociation constant for Ca-EGTA of $4.08 \times 10^{-8} \mathrm{M}$ according to the method of Nanninga and Kempen (1971). Our calculations for free $\mathrm{Ca}^{2+}$ were verified on a computer program graciously provided by Dr. John Dedman, University of Texas Health Science Center, Houston, TX.

\section{CaM preparation}

CaM was purified from bovine brain by the method of Dedman et al. (1977) and demonstrated a single band on disc gel electrophoresis containing $10 \%$ polyacrylamide. $\mathrm{CaM}$ was prepared in the presence of millimolar concentrations of EGTA, dialyzed against $0.05 \mathrm{M}\left(\mathrm{NH}_{4}\right) \mathrm{HCO}_{3}$, and lyophilized. The CaM was redissolved in $10 \mathrm{~m} M$ Tris maleate buffer, $\mathrm{pH} 7.5$. The protein concentration was determined by ultraviolet absorption (Dedman et al., 1977) and the method of Lowry et al. (1951). The $M_{r}$ determined by slab gel electrophoresis using standards of known molecular weight was 16,700 . This mass was used to calculate the concentrations of CaM reported in this study.

\section{Determination of CaM content and cyclic AMP phosphodiesterase assay}

CaM was assayed by its ability to stimulate a CaMdeficient phosphodiesterase prepared from bovine brain as previously described (Gnegy et al., 1977). The CaM content (in nanograms) was determined from a standard curve using highly purified CaM. Phosphodiesterase ac- 
tivity of the retinal particulate fractions was measured under the adenylate cyclase assay conditions with either $2 \mathrm{mM}\left[{ }^{3} \mathrm{H}\right]$ cyclic AMP or $100 \mu M\left[{ }^{3} \mathrm{H}\right]$ cyclic AMP $(0.3$ $\mu \mathrm{Ci}\left[{ }^{3} \mathrm{H}\right]$ per assay). The activity was measured as described by Gnegy et al. (1977).

\section{Materials}

Bovine eyes were obtained fresh from a local slaughterhouse. $\left[\alpha-{ }^{32} \mathrm{P}\right] \mathrm{ATP}$ (specific activity, $38 \mathrm{Ci} / \mathrm{mmol}$ ) was purchased from Amersham/Searle. Arlington Heights, IL. Cyclic AMP, phosphenolpyruvate, ATP, and 3-hydroxytyramine $\mathrm{HCl}$ (DA) were obtained from Sigma Chemical, St. Louis, MO; pyruvate kinase was from Boehringer-Mannheim, Indianapolis, IN. GTP and GppNHp (HPLC purified) were purchased from International Chemical and Nuclear, Irvine, CA.

\section{RESULTS}

CaM-stimulated adenylate cyclase activity in particulate fractions prepared from retinas incubated under dark or light conditions

CaM-stimulated adenylate cyclase activity was measured in washed particulate fractions from bovine retinas dissected under dark conditions and then incubated for $20 \mathrm{~min}$ under dark or light conditions. As shown in Fig. 1A, the activation of adenylate cyclase by $\mathrm{CaM}$ was clearly greater in retinas that had been incubated under dark conditions as compared to light conditions. Adenylate cyclase activity from retinas incubated under light conditions was stimulated nearly eightfold by $1400 \mathrm{nM}$ CaM, a maximum concentration (Fig. 1A). On the contrary, $1400 \mathrm{nM}$ CaM stimulated adenylate cyclase activity 12 -fold in retinas that had been incubated under dark conditions. Eadie-Hofstee analysis of the CaM-stimulated adenylate cyclase activity is shown in Fig. 1B. The apparent $V_{\max }$ of the CaM-stimulated adenylate cyclase activity was $60 \%$ greater in particulate fractions from retinas incubated under dark as opposed to light conditions. The values of the apparent $V_{\max }$ for CaM-stimulated adenylate cyclase activity from retinas incubated under dark and light conditions were $270 \pm 13$ and $170 \pm 16 \mathrm{pmol} / \mathrm{min} / \mathrm{mg}$ protein $(\mathrm{n}=4)$, respectively. The apparent $K_{\mathrm{a}}$ for $\mathrm{CaM}$ was not altered significantly by the change in lighting conditions, being $53 \pm 7$ and $67 \pm 7 \mathrm{n} M$ in dark and light, respectively.

The basal adenylate cyclase activity was not altered by the different lighting conditions; basal activities in particulate fractions from retinas incubated under light or dark conditions were $28 \pm 4$ and $26 \pm 3 \mathrm{pmol} / \mathrm{min} / \mathrm{mg}$ protein, respectively. Similarly, there was no change in $\mathbf{M n}^{2+}$-stimulated adenylate cyclase activity. $\mathrm{Mn}^{2+}(5 \mathrm{mM})$ stimulated adenylate cyclase activity 14 -fold in retinas incubated under either dark or light conditions.

We measured the CaM content in retinal particulate fractions prepared in the absence and presence of EGTA. In non-EGTA-treated retinal partic-
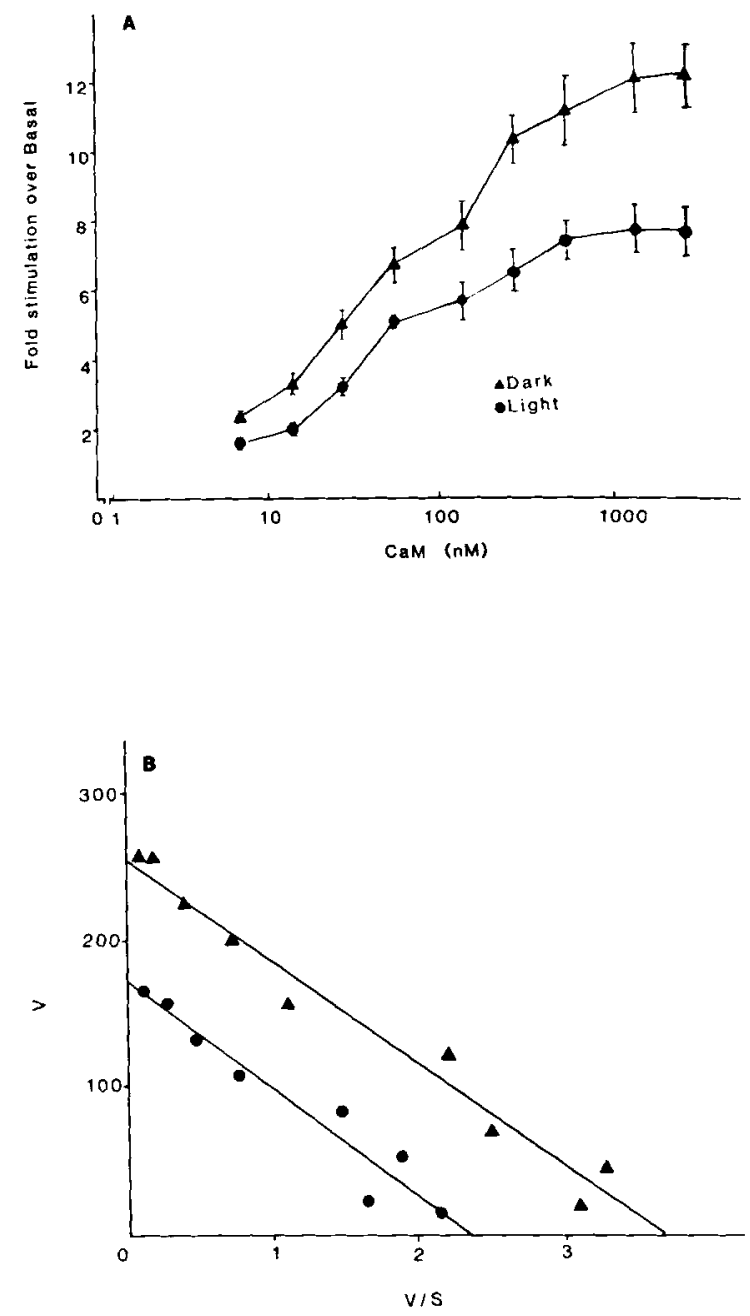

FIG. 1. A: Activation of adenylate cyclase activity by CaM in bovine retinas that have been incubated under dark or light conditions. Bovine retinas were dissected from the eye and incubated under dark ( $\boldsymbol{\Delta})$ or light $(\boldsymbol{O})$ conditions, as described in Materials and Methods. The retinas were washed, and adenylate cyclase was measured in an EGTA-washed particulate fraction. The results are expressed as the foidstimulation by various concentrations of CaM and $0.12 \mu \mathrm{M}$ free $\mathrm{Ca}^{2+}\left(100 \mu \mathrm{M} \mathrm{CaCl}_{2}\right.$ in the assay) over basal adenylate cyclase activity. Basal adenylate cyclase activities from retinas preincubated under dark and light conditions were 26 \pm 3 and $28 \pm 4 \mathrm{pmol} / \mathrm{min} / \mathrm{mg}$ protein, respectively. Each point represents the average \pm SEM for four separate determinations. B: Eadie-Hofstee analysis of CaM-stimulated adenylate cyclase activity in bovine retinas that have been incubated under dark ( $\mathbf{A})$ or light (O) conditions. The velocity (V) is given in $\mathrm{pmol} / \mathrm{min} / \mathrm{mg}$ protein, and the substrate (S) is in $\mathrm{nM}$ units. Kinetic constants for CaM-stimulated adenylate cyclase in retinas incubated under dark conditions were: apparent $V_{\max }, 270 \pm 13 \mathrm{pmol} / \mathrm{min} / \mathrm{mg}$ protein and apparent $K_{\mathrm{a}}$, $53 \pm 7 \mathrm{nM}$. Under light conditions, the constants were: apparent $V_{\max }, 170 \pm 13 \mathrm{pmol} / \mathrm{min} / \mathrm{mg}$ protein $(p<0.002$ as compared to value for dark-incubated retinas), and apparent $K_{\mathrm{a}}, 67 \pm 7 \mathrm{nM}$. The number of determinations is four for both groups. 
ulate fractions prepared as described in Materials and Methods, the concentration of $\mathrm{CaM}$ was $5.9 \mu \mathrm{g}$ $\mathrm{CaM} / \mathrm{mg}$ membrane protein (total CaM in the particulate fraction was $210 \mathrm{mg} \mathrm{CaM} / \mathrm{g}$ tissue wet weight). The CaM concentration in the remaining cytosol was $11.4 \mu \mathrm{g} \mathrm{CaM} / \mathrm{mg}$ protein (total $\mathrm{CaM}$ in the cytosol was $243 \mathrm{mg} \mathrm{CaM} / \mathrm{g}$ tissue wet weight). The concentration of CaM in either the particulate or soluble retinal fractions did not change as a result of differences in lighting conditions. Treatment of the fractions with EGTA depleted approximately $60-70 \%$ of the CaM in the particulate fraction. Similarly, the residual CaM content in the EGTAwashed particulate fractions from retinas incubated under dark or light conditions was the same. Therefore, the change in activation of adenylate cyclase by CaM occurring under different lighting conditions was not due to different levels of endogenous $\mathrm{CaM}$ remaining in the membrane.

We examined the cyclic AMP phosphodiesterase activity in the particulate fractions from retinas exposed to light and dark conditions. A light-activated cyclic GMP phosphodiesterase activity has been demonstrated in rod outer segments (Miki et al., 1973; Goridis and Virmaux, 1974). We explored whether the decrease in cyclic AMP production in particulate fractions from light-incubated retinas could be due to an increase in cyclic AMP phosphodiesterase activity. Phosphodiesterase activity was measured using the same concentration of cyclic AMP that is included in the adenylate cyclase assay under the identical conditions. We found no significant difference in cyclic AMP phosphodiesterase activity in particulate fractions from retinas incubated in light or dark conditions, being 1085 and $1424 \mathrm{nmol} / \mathrm{min} / \mathrm{mg}$ protein, respectively. These results were obtained from two retinas in each group and the values did not differ by more than 10 percent. Similarly, we found no difference in phosphodiesterase activity measured at another concentration of cyclic AMP, $100 \mu M$, in retinas incubated under light and dark conditions ( 325 and $300 \mathrm{pmol} /$ $\mathrm{min} / \mathrm{mg}$ protein, respectively).

\section{$\mathrm{Ca}^{2+}$-sensitivity of adenylate cyclase in retinas} incubated under dark or light conditions

The experiments described above were performed in the presence of $100 \mu M \mathrm{CaCl}_{2}$ which results in a free $\mathrm{Ca}^{2+}$ concentration of $0.12 \mu M$ in the assay. Activation of adenylate cyclase by $\mathrm{CaM}$ is dependent on the presence of $\mathrm{Ca}^{2+}$. The difference in stimulation of the enzyme of CaM in retinas incubated under the different lighting conditions may be due to a change in sensitivity to $\mathrm{Ca}^{2+}$. The $\mathrm{Ca}^{2+}$ dependence curve for stimulation of adenylate cyclase by $\mathrm{CaM}$ in the particulate fractions from retinas incubated under dark or light conditions indicates that $\mathrm{Ca}^{2+}$ in the absence of $\mathrm{CaM}$ did not stimulate adenylate cyclase activity (Fig. 2 ). In the

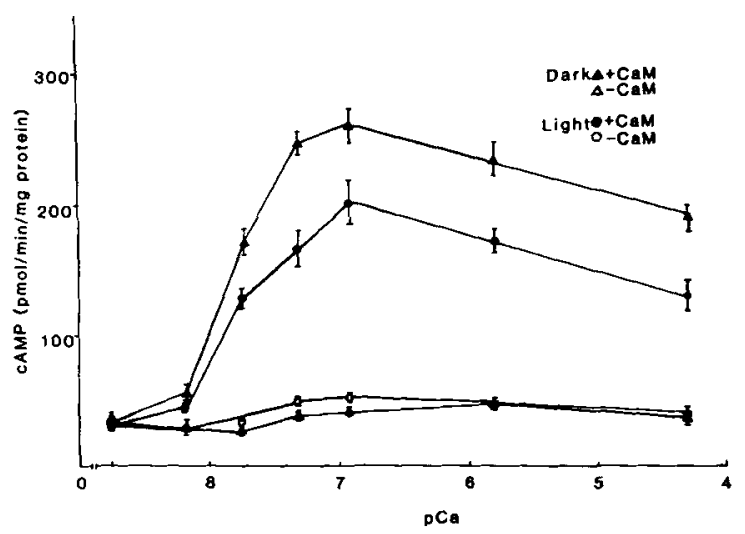

FIG. 2. $\mathrm{Ca}^{2+}$ dependence of $\mathrm{CaM}$ activation of adenylate cyclase in retinas incubated under light or dark conditions. Adenylate cyclase activity was measured in particulate fractions prepared from retinas that had been preincubated under dark $(\Delta, \Delta)$ or light $(0,0)$ conditions, as described under Materials and Methods. Activation of adenylate cyclase activity by $\mathrm{Ca}^{2+}$ was determined in the absence $(\Delta, 0)$ and presence $(\Delta, \theta)$ of $280 \mathrm{nM}$ CaM. Each point represents the average \pm SEM of three separate determinations.

presence of $\mathrm{Ca}^{2+}$, however, CaM was active in stimulating adenylate cyclase activity, and the activity was greater in retinas incubated under dark as opposed to light conditions. As the data of Fig. 2 illustrate, activation of adenylate cyclase by $\mathrm{CaM}$ was maximal at $0.12 \mu M \mathrm{Ca}^{2+}$ in particulate fractions from retinas incubated under either dark or light conditions. This is the concentration of $\mathrm{Ca}^{2+}$ at which there is maximum $\mathrm{CaM}$ stimulation of adenylate cyclase in brain (Gnegy and Treisman, 1981). The curves were slightly biphasic; activation by CaM was decreased by free $\mathrm{Ca}^{2+}$ concentrations greater than $0.12 \mu M$. These data demonstrated that the change in CaM-stimulated activity in retina incubated under dark conditions was not due to an alteration in sensitivity of the enzyme for $\mathrm{Ca}^{2+}$.

DA-stimulated adenylate cyclase activity in retinas preincubated under dark or light conditions

The effect of dark or light incubation conditions on the activation of adenylate cyclase in retinal particulate fractions by DA was examined. Stimulation of adenylate cyclase activity by DA required GTP, although GTP itself poorly activated adenylate cyclase activity. Activation of adenylate cyclase by DA in the presence of $1 \mu M$ GTP in particulate fractions from retinas incubated under light or dark conditions is shown in Fig. 3A. As shown by the symbols at the ordinate, activation of adenylate cyclase by GTP was not altered by incubating the retinas under dark or light conditions. The response of the enzyme to DA, however, was significantly greater in particulate fractions from retinas incu- 


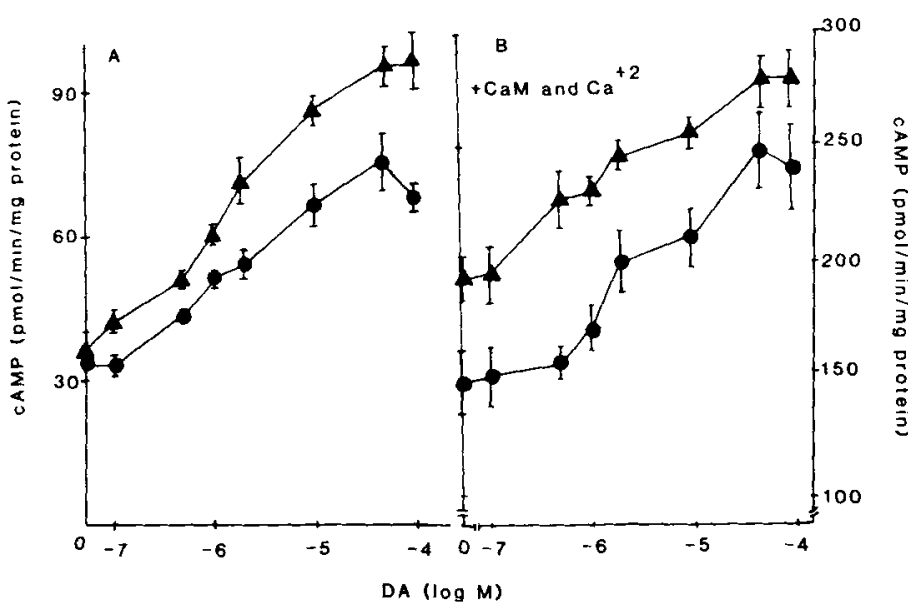

FIG. 3. A: Dose-dependent activation of adenylate cyclase by DA in particulate fractions from retinas incubated under dark or light conditions. Adenylate cyclase was measured, as described in Materials and Methods, in particulate fractions in the presence of $1 \mu M$ GTP prepared from retinas that had been incubated under dark (A) or light (1) conditions. Each point represents the average $\pm S E M$ of four separate determinations. B: Dose-dependent activation of adenylate cyclase by DA in the presence of $\mathrm{Ca}^{2-}$ and $\mathrm{CaM}$ in retinas incubated under dark or light conditions. Adenylate cyclase activity was measured, as described in Materials and Methods, in particulate fractions from retinas that had been incubated under dark $(\boldsymbol{\Delta})$ or light (C) conditions. Assays contained $1 \mu M$ GTP, $0.12 \mu \mathrm{M}$ free $\mathrm{Ca}^{2+}\left(100 \mu \mathrm{M}\right.$ added $\left.\mathrm{CaCl}_{2}\right)$, and $280 \mathrm{nM}$ CaM with various concentrations of DA. Each point represents the average \pm SEM of four separate determinations. bated under dark as opposed to light conditions. The apparent kinetic constants for the DA-stimulated adenylate cyclase activities were calculated from the data of Fig. 3A using Eadie Hofstee analysis and are shown in Table 1. DA-stimulated adenylate cyclase activity is defined as the pmol cyclic $\mathrm{AMP} / \mathrm{min} / \mathrm{mg}$ protein formed above the activity produced in the presence of GTP alone. The apparent $V_{\max }$ for DA activation of adenylate cyclase in particulate fractions from retinas incubated under dark conditions was significantly greater than that from retinas incubated under light conditions. There was no significant difference in the affinity for DA between the two groups, however.

The activation of adenylate cyclase by DA in the presence of $\mathrm{Ca}^{2+}$ and $\mathrm{CaM}$ in retinas incubated under dark or light conditions was determined (Fig. 3B). As shown by the symbols at the ordinate of Fig. 3B, the adenylate cyclase activity in the presence of $0.12 \mu M \mathrm{Ca}^{2+}$ and $280 \mathrm{nMCaM}$ was greater in retinas incubated under dark as opposed to light conditions. The data in Fig. 3B reveal that activation of adenylate cyclase in the presence of $\mathrm{Ca}^{2+}$ and $\mathrm{CaM}$ was greater in particulate fractions from retinas incubated in dark as opposed to light conditions. The increased adenylate cyclase activity in dark-incubated retinas was not apparent at high DA concentrations, however. This suggests that a maximum adenylate cyclase activity may have been reached by addition of the exogenous CaM. It is possible that the enzyme is partially activated by a CaM-related process in the dark. The apparent kinetic constants for the DA-stimulated adenylate cyclase activity (that activity stimulated by DA above that of GTP, $\mathrm{Ca}^{2+}$, and $\mathrm{CaM}$ ) calculated from the data of Fig. 3B are shown in Table 1. The apparent $K_{\mathrm{a}}$ and the apparent $V_{\max }$ for DA in particulate fractions preincubated under light or dark conditions were the same when measured in the presence of $\mathrm{Ca}^{2+}$ and $\mathrm{CaM}$.

It can be further demonstrated from the data of Fig. 3 and Table 1 that DA was able to stimulate the

TABLE 1. Kinetic constants for stimulation of DA-sensitive adenylate cyclase activity in retinas incubated under dark or light conditions

\begin{tabular}{llcc}
$\begin{array}{c}\text { Incubation } \\
\text { lighting }\end{array}$ & $\begin{array}{c}\text { Adenylate cyclase } \\
\text { assay } \\
\text { addition }\end{array}$ & $\begin{array}{c}K_{\mathrm{a}}^{\mathrm{app}} \\
(\mu M)\end{array}$ & $\begin{array}{c}V_{\text {max }}^{\text {app }} \\
\text { (pmol/min/mg protein) }\end{array}$ \\
\hline Light & GTP & $1.8 \pm 0.3$ & $39 \pm 4$ \\
& GTP, $\mathrm{Ca}^{2+}, \mathrm{CaM}$ & $1.2 \pm 0.3$ & $102 \pm 14$ \\
Dark & GTP & $1.3 \pm 0.2$ & $61 \pm 7^{b}$ \\
& GTP, $\mathrm{Ca}^{2+}, \mathrm{CaM}$ & $0.8 \pm 0.1$ & $104 \pm 11$ \\
\hline
\end{tabular}

${ }^{a}$ Activation of adenylate cyclase by DA was measured in the presence of $1 \mu M$ GTP or $1 \mu M$ GTP plus $0.12 \mu M$ free $\mathrm{Ca}^{2+}\left(100 \mu M\right.$ added $\left.\mathrm{CaCl}_{2}\right)$ and $280 \mathrm{n} M$ CaM. DA-stimulated adenylate cyclase activity is defined as the pmol of cyclic AMP per min per mg protein formed by DA above that produced in the presence of GTP or GTP, $\mathrm{Ca}^{2+}$, and CaM. Kinetic constants were calculated by EadieHofstee analysis from the data shown in Fig. 3.

${ }^{b} \mathrm{p}<0.05$ as compared to value with GTP for retina incubated under light. Values are means \pm SEM for four separate experiments. 
production of more cyclic AMP in the presence as opposed to the absence of $\mathrm{Ca}^{2+}$ and $\mathrm{CaM}$. The maximal activity of DA-stimulated adenylate cyclase was $40 \mathrm{pmol} / \mathrm{min} / \mathrm{mg}$ protein in the absence of $\mathrm{Ca}^{2+}$ and CaM (Fig. 3A. Table 1) but $102 \mathrm{pmol} / \mathrm{min} / \mathrm{mg}$ protein in the presence of $\mathrm{Ca}^{2+}$ and CaM (Fig. 3B, Table 1). $\mathrm{Ca}^{2+}$ and CaM could similarly increase the response to DA in particulate fractions from retinas incubated in the dark, but not to as great an extent (Table 1).

Effect of lighting on guanyl nucleotide-stimulated adenylate cyclase activity

Since guanyl nucleotides are required for DAstimulation of adenylate cyclase activity (Gnegy and Treisman, 1981), we examined activation of the enzyme by GTP and the nonhydrolyzable GTP analog, GppNHp, in retinas incubated under dark or light conditions. The effect of incubation lighting conditions on GTP stimulation of retinal adenylate cyclase is shown in Table 2. GTP was a weak activator of retinal adenylate cyclase activity. The data in Table 2 demonstrate that activation of adenylate cyclase by GTP in the retinal particulate fractions was not altered by incubating the retinas under light or dark conditions.

The nonhydrolyzable GTP analog, GppNHp, was a much more potent activator of retinal adenylate cyclase than was GTP. The effect of light or dark incubation conditions on the activation of retinal adenylate cyclase activity by GppNHp is shown in Fig. 4. Stimulation of adenylate cyclase activity by $\mathrm{GppNHp}$ was greater in particulate fractions from retinas incubated under dark as opposed to light conditions. The maximum activation of adenylate cyclase by $\mathrm{GppNHp}$ was $66 \%$ greater in particulate fractions from retinas incubated under dark conditions. The apparent $V_{\max }$ for activation of adenylate cyclase by GppNHp above basal was $104 \pm 9 \mathrm{pmol} /$ $\mathrm{min} / \mathrm{mg}$ protein in fractions from retinas incubated under light conditions and $173 \pm 16 \mathrm{pmol} / \mathrm{min} / \mathrm{mg}$ protein in fractions from retinas incubated under

TABLE 2. Activation of adenylate cyclase by GTP in particulate fractions prepared from retinas incubated under dark or light conditions

\begin{tabular}{ccc}
\hline & \multicolumn{2}{c}{$\begin{array}{c}\text { Adenylate cyclase activity } \\
\text { (pmol/min/mg protein) }\end{array}$} \\
\hline GTP & \multicolumn{1}{c}{ LM } & Dark \\
\hline 0.0 & $28 \pm 5$ & $28 \pm 3$ \\
0.1 & $33 \pm 7$ & $32 \pm 1$ \\
1.0 & $36 \pm 5$ & $38 \pm 2$ \\
10.0 & $44 \pm 7$ & $45 \pm 4$ \\
\hline
\end{tabular}

a Adenylate cyclase activity was measured in particulate fractions from retinas incubated under dark or light conditions as described in Materials and Methods.

$b$ Values are the averages \pm SEM of four separate determinations.

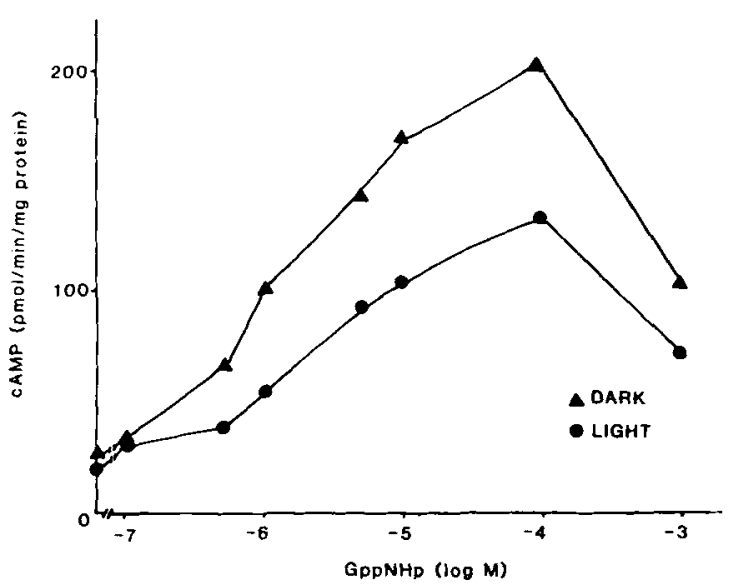

FIG. 4. Activation of adenylate cyclase by GppNHp in particulate fractions from retinas preincubated under dark or light conditions. Adenylate cyclase activity was measured, as described in Materials and Methods, in particulate fractions prepared from retinas that had been preincubated under dark $(\Delta)$ or light $(\boldsymbol{O})$ conditions. Each point represents the average of two separate determinations performed in duplicate which did not vary by more than $5 \%$.

dark conditions. The affinity of adenylate cyclase for GppNHp was not changed by altering the incubation lighting conditions. The apparent $K_{\mathrm{a}} \mathrm{s}$ for GppNHp in retinas preincubated under dark or light conditions were $2.3 \mu M$ and $2.4 \mu M$, respectively. GppNHp activated adenylate cyclase at concentrations from $0.1 \mu M$ to $100 \mu M$, but the activity decreased at $1 \mathrm{mM}$. The decline in activity was comparable whether the retinas were incubated under dark or light conditions.

$\mathrm{CaM}$ could further activate adenylate cyclase activity in the presence of GppNHp, although at maximal concentrations of both effectors the activation was less than additive. Maximal adenylate cyclase activity in the presence of $100 \mu M \mathrm{GppNHp}$ and 1.4 $\mu M \mathrm{CaM}$ in particulate fractions from retinas incubated under dark or light conditions was 332 and $240 \mathrm{pmol} / \mathrm{min} / \mathrm{mg}$ protein, respectively.

\section{Adenylate cyclase activity in bovine retinas preincubated under dark conditions in the presence of DA}

Kramer (1971) demonstrated that light could elicit the release of DA in mammalian neural retina. It is possible that the decreased responsiveness of adenylate cyclase to CaM, DA, and GppNHp by light exposure is due to a down-regulation of DA receptor activity as a consequence of increased exposure to released DA. To explore this possibility, we incubated retinas under light and dark conditions in the presence and absence of $10 \mu M$ DA. All incubations contained $100 \mu M$ ascorbic acid. After incubation, the retinas were washed as described in Materials and Methods, and the response 
of adenylate cyclase to CaM, DA, and GppNHp was measured in the particulate fractions. The dose-dependent increase in adenylate cyclase activation by $\mathrm{CaM}$ in particulate fractions from retinas incubated under dark and light conditions with and without $10 \mu M \mathrm{DA}$ is shown in Fig. 5. It can be seen that the activation of adenylate cyclase by $\mathrm{CaM}$ incubated under dark conditions is significantly reduced by the addition of DA and resembles that of retinas incubated in the light. As shown in Fig. 5, addition of DA to retinas incubated in light did not alter the activation of adenylate cyclase by $\mathrm{CaM}$ from that obtained in light alone.

The activation of adenylate cyclase by $\mathrm{GppNHp}$ and DA was similarly decreased by the presence of DA in retinas incubated in the dark. Maximal activations of adenylate cyclase by $100 \mu M \mathrm{GppNHp}$ in particulate fractions from retinas incubated under conditions of dark, dark + DA, and light are 228 , 161 , and $154 \mathrm{pmol} / \mathrm{min} / \mathrm{mg}$ protein, respectively. DA-stimulated adenylate cyclase activities measured at $100 \mu M \mathrm{DA}$ in particulate fractions from retinas incubated under conditions of dark, dark + $\mathrm{DA}$, and light are 65,42 , and $40 \mathrm{pmol} / \mathrm{min} / \mathrm{mg}$ protein, respectively. These data were obtained using two retinas in each group, and the results did not vary by more than 5 percent. Addition of DA to retinas incubated in the light did not alter the acti-

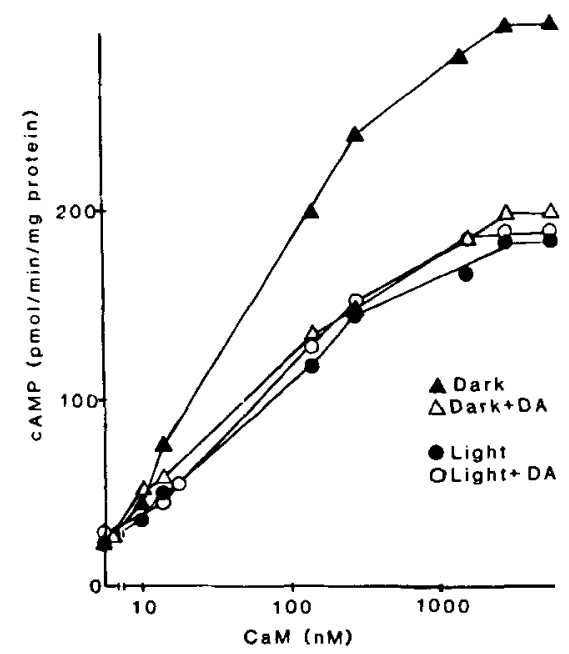

FIG. 5. Activation of adenylate cyclase activity by CaM in bovine retinas that have been incubated under dark or light conditions with or without DA. Bovine retinas were dissected from the eye and incubated, as described in Materials and Methods, in the absence of DA under dark (A) or light (O) conditions or in the presence of $10 \mu M$ DA under dark $(\triangle)$ or light $(O)$ conditions. All incubations contained $100 \mu M$ ascorbic acid. The dose-dependent activation of adenylate cyclase by CaM in the presence of $0.12 \mu M$ free $\mathrm{Ca}^{2+}(100$ $\mu \mathrm{M} \mathrm{CaCl}_{2}$ in the assay) was measured in particulate fractions prepared from the retinas, as described in Materials and Methods. Each point represents the average of two experiments performed in triplicate whose results did not vary by more than $5 \%$. vation of adenylate cyclase by DA and GppNHp from that obtained in light alone. Basal adenylate cyclase activity, as shown on the ordinate of Fig. 5 , was the same under all conditions.

\section{DISCUSSION}

Neural retina contains a DA receptor-coupled adenylate cyclase activity. We and others (Spano et al., 1977; Watling et al., 1980; Watling and Dowling. 1981) have shown that the ability of DA to activate adenylate cyclase activity and produce cyclic AMP in the retina can be modulated by light. This study has demonstrated that adenylate cyclase activity in bovine retina is highly responsive to the endogenous $\mathrm{Ca}^{2+}$-binding protein, CaM, and that this activity can be regulated by light in a manner similar to that of DA stimulation. CaM stimulated adenylate cyclase activity 12 -fold in retinas that had been incubated under dark conditions. On the contrary, the stimulation by $\mathrm{CaM}$ was only eightfold in retinas that had been incubated under light conditions. Activation of adenylate cyclase by DA and $\mathrm{GppNHp}$ was similarly greater in particulate fractions from retinas incubated under dark as opposed to light conditions. Our results suggest that the stimulation of adenylate cyclase by $\mathrm{CaM}$ may be under the same neural regulation as that of DA stimulation of adenylate cyclase and that they may represent modifiers of the same enzyme.

A possible explanation for the alteration in activation of adenylate cyclase by DA in retinas preincubated under dark or light conditions is a modulation of activity of DA receptors in the membrane. Significant DA release has been demonstrated to occur in retinas exposed to light (Kramer, 1971). The increased activation of the DA receptors by the released DA could result in a compensatory subsensitivity of DA receptors. Conversely, under dark conditions, when less DA is being released, the receptor sensitivity would be greater. This interpretation is supported by our finding that activation of adenylate cyclase by CaM, GppNHp, and DA in particulate fractions from retinas incubated under dark conditions with exogenous DA is the same as that from retinas incubated in the light. Hedden and Dowling (1978) have shown that continuous red light did not activate dopaminergic interplexiform cells to release DA in the carp. Exposure to continuous red light thus resulted in a decrease in cyclic AMP formation in carp retina as compared to the increase in cyclic AMP attained after activation by flashing light (Watling and Dowling, 1981). Similarly, Spano et al. (1977) found an increase in DA stimulation of adenylate cyclase activity in retinas from rats that had been kept in continuous dark for $65 \mathrm{~h}$, suggesting again a supersensitivity of DA receptors resulting from decreased DA release. The decreased responsiveness of adenylate cyclase activity in particulate fractions from retinas incubated 
in light does not appear to be due to a change in phosphodiesterase activity, although there is a cyclic GMP-dependent phosphodiesterase activity increased by light in rod outer segments (Miki et al., 1973; Goridis and Virmaux, 1974). The phosphodiesterase activity measured under our assay conditions at two different concentrations of cyclic AMP was approximately the same, regardless of whether the retinas were incubated under dark or light conditions. Basal, $\mathrm{Mn}^{2+}-$, and GTP-stimulated adenylate cyclase activities were not changed in particulate fractions from retinas incubated under light as opposed to dark conditions, further suggesting that a phosphodiesterase activity is not involved in the results.

These studies suggest that a form of adenylate cyclase that is sensitive to DA. CaM, and GppNHp is being affected by light. This concept is supported hy the work of DeVries et al. (1982). Retinas from hoth squirrel and rabbit had adenylate cyclase activity in the inner plexiform layer that was activated by DA and GppNHp and inhibited by EGTA, suggesting $\mathrm{Ca}^{2+}$-dependent activation. This may not be, of course, the only adenylate cyclase activity in the retina. An involvement of CaM with DA is also demonstrated by the ability of $\mathrm{CaM}$ to increase maximal stirnulation of adenylate cyclase activity by DA. CaM could increase the apparent $V_{\max }$ for DA whether the retinas had been incubated under dark or light conditions. In the presence of CaM and a maximal concentration of DA, however, there was no difference in adenylate cyclase activity in retinas incubated under light or dark conditions (Fig. 3B). This could suggest that the enzyme was previously activated by a CaM-dependent process while incubating in the dark and responded less well to exogenous CaM. There is a finite limit to which adenylate cyclase can be activated by these effectors. The maximum level of adenylate cyclase attained in the presence of CaM and DA or CaM and GppNHp was approximately $300-330 \mathrm{pmol} / \mathrm{min} / \mathrm{mg}$ protein.

Our studies demonstrated that activation of adenylate cyclase by a DA receptor mechanism, the GTP-binding transducing component (designated as $\mathrm{N}$ ), and a CaM-responsive component is altered by light. The molecular mechanism by which CaM activates adenylate cyclase is not known, but recent studies suggest that $\mathrm{CaM}$ does not require GTP for its activity (Heideman et al., 1982; Seamon and Daly, 1982) and may act directly at the catalytic subunit (Salter et al.. 1981). Several studies suggest that $\mathrm{CaM}$ can affect $\mathrm{N}$-mediated activity (Brostrom et al., 1978; Treisman et al., 1983), and we have found that CaM can increase the sensitivity and maximal response of adenylate cyclase to $\mathrm{DA}$ in striatum (Gnegy and Treisman, 1981) and retina, respectively. The effect of light on CaM activation, as well as receptor and $\mathrm{N}$-related processes, suggests that the down-regulation could involve a site on the catalytic subunit influenced by both CaM and $\mathbf{N}$ but does not alter basal activity. There was no change in GTP stimulation, however, in particulate fractions from retinas incubated under light conditions. It is possible that GDP is bound tightly to the $N$ involved and cannot be displaced by GTP in the absence of DA. The light-induced alterations in adenylate cyclase activity occur in a very short time, suggesting that the intracellular molecular mechanism for the sensitivity change may involve a covalent enzyme modification or a dissociation-reassociation of certain subunits.

In conclusion, we have shown that light can modulate the stimulation of adenylate cyclase activity in retina by CaM, DA, and GppNHp. This suggests that the level of dopaminergic activity, which is increased by light, can alter receptor activity. Although the cellular localization of the enzyme(s) affected by these agents is not shown, the fact that both CaM and guanyl nucleotides affect DA sensitivity and are altered by light suggest they may be activating the same enzyme. Our studies show that stimulation of adenylate cyclase activity by $\mathrm{CaM}$ in retina is under neural control and suggest that $\mathrm{CaM}$ may be an endogenous modulator of DA-sensitive adenylate cyclase activity.

Acknowledgments: This work was supported by the grant RO1 MH36044-02 from the National Institute of Mental Health. The helpful advice by Drs. Michael luvone and Richard Neubig is gratefully acknowledged. We would like to thank Lynn Iwaniec and Linda Harbison for their help in preparation of this manuscript.

\section{REFERENCES}

Brostrom M. A., Brostrom C. O., and Wolff D. J. (1978) Calcium-dependent adenylate cyclase from rat cerebral cortex: activation by guanine nucleotides. Arch. Biochem. Biophys. $191,341-350$.

Brown J. H. and Makman M. H. (1972) Stimulation by dopamine of adenylate cyclase in retinal homogenates and adenosine $3^{\prime}: 5^{\prime}$-cyclic monophosphate formation in intact retina. Proc. Natl. Acad. Sci, USA 69, 539-543.

Dedman J. R.. Potter J. D.. Jackson R. L., Johnson J. D., and Means A. R. (1977) Physicochemical properties of rat testis $\mathrm{Ca}^{2+}$-dependent regulator protein of cyclic nucleotide phosphodiesterase. Relationship of $\mathrm{Ca}^{2-}$-binding, conformational changes, and phosphodiesterase activity. J. Biol. Chem. 252, 8415-8422.

DeVries G. W., Campau K. M., and Ferrendelli J. A. (1982) Adenylate cyclases in the vertebrate retina: distribution and characteristics in rabbit and ground squirrel. $J$. Neurochem. $38,759-765$.

Dowling J. E. and Ehinger B. (1978) The interplexiform cell system. I. Synapses of the dopaminergic neurones of the goldfish retina. Proc. R. Soc. Lond. [Biol.] 201, 7-26.

Ferrendelli J. A.. Campau K. M. and DeVries G. W. (1982) Adenylate cyclases in vertebrate retina: enzymatic characteristics in normal and dystrophic mouse retina. J. Neurochem. $38,753-758$.

Gnegy M. E. (1982) Relat:onship of calmodulin and dopaminergic activity in the striatum. Fed. Proc. 41, 2273-2277.

Gnegy M. and Treisman G. (1981) Effect of calmodulin on do- 
pamine sensitive adenylate cyclase activity in rat striatal membranes. Mol. Pharmacol. 19, 256-263.

Gnegy M. E.. Nathanson J. A., and Uzunov P. (1977) Release of the phosphodiesterase activator by cyclic AMP-dependent ATP: protein phosphotransferase from subcellular fractions of rat brain. Biochim. Biophys. Acta 497, 75-85.

Goridis C. and Virmaux N. (1974) Light-regulation of guanosine 3'.5'-monophosphate phosphodiesterase of bovine retina. Nature 248, 57-58.

Hedden W. L. and Dowling J.E. (1978) The interplexiform cell system. II. Effects of dopamine on goldfish retinal neurones. Proc. $R$. Soc. Lond. (Biol.) 201, 27-55.

Heideman W., Wierman B. M., and Storm D. R. (1982) GTP is not required for calmodulin stimulation of bovine brain adenylate cyclase. Proc. Natl. Acad. Sci. USA 79, 1462-1465.

Iuvone P. M., Galli C. L., Garrison-Gund C. K., and Neff N. H. (1978) Light stimulates tyrosine hydroxylase activity and dopamine synthesis in retinal amacrine neurons. Science 202, $901-902$.

Kramer S. G. (1971) Dopamine: a retinal neurotransmitter. I. Retinal uptake, storage and light stimulated release of ${ }^{3} \mathrm{H}-$ dopamine in vivo. Invest. Ophthamol. 10, 438-452.

Krishna G., Weiss B., and Brodie B. B. (1968) A simple, sensitive method for the assay of adenylate cyclase. J. Pharmacol. Exp. Ther. 163, 379-385.

Lolley R. N. (1980) Cyclic nucleotide metabolism in the vertebrate retina. Curr. Topics Eye Res. 2, 67-118.

Lowry O. H., Rosebrough N. J., Farr A.L., and Randall R. J. (1951) Protein measurement with the folin phenol reagent J. Biol. Chem. 193, 265-275.

Makman M. H., Dvorkin B., Horowitz S. G., and Thal L. J. (1980) Properties of dopamine agonist and antagonist binding sites in mammalian retina. Brain Res. 194, 403-418.

Miki N., Keims J. J., Marcus F. R., Freeman J., and Bitensky M. W. (1973) Regulations of cyclic nucleotide concentrations in photoreceptors: an ATP-dependent stimulation of cyclic nucleotide phosphodiesterase by light. Proc. Natl. Acad. Sci. USA 76, 3820-3824.

Muirhead N., Treisman G., Simpson P., and Gnegy M.E. (1983) Calmodulin-stimulated adenylate cyclase activity in bovine retina. Soc. Neurosci. Abstr. 9, 86.

Nanninga B. and Kempen R. (1971) Role of magnesium and cal- cium in the first and second contraction of glycerin-extracted muscle fibers. Biochemistry 10, 2449-2456.

Redburn D. A., Clement-Cormier Y., and Lam D. M. K. (1980) Dopamine receptors in the goldfish retina: ${ }^{3} \mathrm{H}$-spiroperidol and ${ }^{3} \mathrm{H}$-domperidone binding: and dopamine-stimulated adenylate cyclase activity. Life' $S c i$. 27, 23-31.

Salter R. S., Krinks M. H., Klee C. B., and Neer E. J. (1981) Calmodulin activates the isolated catalytic unit of brain adenylate cyclase. J. Biol. Chem. 256, 9830-9833.

Seamon K. B. and Daly J. W. (1982) Calmodulin stimulation of adenylate cyclase in rat brain membranes does not require GTP. Life Sci. 30, $1457-1467$.

Spano P. F., Govoni S., Hofmann M.. Kumakura K., and Trabucchi M. (1977) Physiological and pharmacological influences on dopaminergic receptors in the relina. Ads. Biochem. Psychopharm. 16, 307-310.

Thomas T. N., Clement-Cormier Y. C., and Redburn D. A. (1978) Uptake and release of $\left[{ }^{3} \mathrm{H}\right]$ dopamine and dopaminesensitive adenylate cyclase activity in retinal synaptosomal fractions. Brain Res. 155, 391-396.

Treisman G. J., Bagley S., and Gnegy M. E. (1983) Calmodulinsensitive and calmodulin-insensitive components of ade nylate cyclase activity in rat striatum have differential responsiveness to guanyl nucleotides. $J$. Neurochem. 41, $1398-1406$

Watling K. J. and Dowling J. E. (1981) Dopaminergic mechanisms in the teleost retina. I. Dopamine sensitive adenylate cyclase in homogenates of carp retina; effects of agonists. antagonists and ergots. $J$. Neurochem. 36, 559-568.

Watling K. J. and Iversen L. L. (1981) Comparison of the binding of $\left[{ }^{3} \mathrm{H}\right]$ spiperone and $\left[{ }^{3} \mathrm{H}\right]$ domperidone in homogenates of mammalian retina and caudate nucleus. $J$. Neurochem. $37,1130-1143$.

Watling K. J., Dowling J. E., and Iversen L. L. (1979) Dopamine receptors in the retina may be all linked to adenylate cy. clase. Nature 281, 578-580.

Watling K. J., Dowling J. E., and Iversen L. L. (1980) Dopaminergic mechanisms in the carp retina: effects of dopamine, $\mathrm{K}^{+}$and light on cyclic AMP synthesis, in : Neurochemistry of the Retina (Bazan N. and Lolley R. eds), pp. 519-537. Pergamon Press, New York. 